\title{
Radosław Zarzecki
}

\section{Uwarunkowania procesu pojednania w Kambodży}

Czterdzieści pięć lat temu, w kwietniu 1975 r., społeczność międzynarodowa po raz kolejny zwróciła swój wzrok w stronę Indochin. Po dziesiątkach lat walk, mających wymiar zarówno wewnętrzy, jak i międzynarodowy, siły komunistyczne przejęły władzę w Wietnamie i Kambodży. Symbolem tych wydarzeń stały się pełne tragizmu nagrania pokazujące ewakuację amerykańskich obywateli z Sajgonu, która miała miejsce 29-30 IV 1975 r. ${ }^{1}$. Dwa tygodnie wcześniej, w pobliskiej Kambodży, stolica tego państwa również została przejęta przez ugrupowanie komunistyczne, jednakże towarzyszące temu okoliczności okazały się być dużo bardziej tragiczne. Z dniem upadku Phnom Penh, 17 IV 1975 r., datuje się początek rządów Czerwonych Khmerów. To ekstremistyczne ugrupowanie, założone w latach 50. XX w. w Paryżu przez pochodzących z Kambodży studentów, wykorzystało postępującą destabilizację sytuacji społeczno-politycznej w ich rodzimym kraju. Ich rola szczególnie wzrosła w trakcie prowadzonych przez USA bombardowań Republiki Khmerów, w których zginęło kilkaset tysięcy cywilów², a także po przeprowadzonym w 1970 r. zamachu stanu, w którym obalony został król Norodom Sihanouk, a przywódcą państwa został proamerykański generał Lon Nol. W latach 1970-1973 stali się oni najważniejszą siłą opozycyjną w kraju, cieszyli się poparciem pozbawionego tronu króla, otrzymywali pomoc finansową i militarną od Chińskiej Republiki Ludowej i Wietnamu Północnego ${ }^{3}$. To wszystko ostatecznie pozwoliło im zwyciężyć w trwającej do 1975 r. wojnie domowej.

Ewakuowano także Wietnamczyków, którzy wcześniej współpracowali z władzami Republiki Wietnamu. Zob. D. Lamothe, Vietnam remembered: The fall of Saigon in photos, 40 years later, „The New York Times”, 30 IV 2015, https://www.washingtonpost.com/news/checkpoint/ $\mathrm{wp} / 2015 / 04 / 30 /$ vietnam-remembered-the-fall-of-saigon-in-photos-40-years-later/ (5 V 2020).

2 T. Owen, B. Kiernan, Bombs over Cambodia, „The Asia-Pacific Journal”, 12 V 2007, https:// apjjf.org/-Ben-Kiernan--Taylor-Owen/2420/article.pdf (5 V 2020).

3 C. Wang, The Chinese Communist Party's Relationship with the Khmer Rouge in the 1970s: An Ideological Victory and a Strategic Failure, „CWIHP Working Paper 88”, grudzień 2018, https://www.wilsoncenter.org/publication/the-chinese-communist-partys-relationship-thekhmer-rouge-the-1970s-ideological-victory (5 V 2020). 
Po przejęciu władzy Czerwoni Khmerzy wprowadzili skrajnie totalitarny, oparty na marksizmie ustrój, starając się całkowicie odmienić sytuację polityczno-społeczną w kraju. Już w pierwszy dzień po upadku reżimu Lon Nola przeprowadzili bezprecedensową akcję wysiedlenia wszystkich mieszkańców stolicy, zamieszkanej wówczas przez prawie dwa miliony osób. Niemal wszyscy mieszkańcy Phnom Penh, którym nie udało się znaleźć schronienia, bądź uciec poza granice kraju4, zostali skierowani do przymusowej pracy na prowincji. Taki sam los spotkał w następnych tygodniach znakomitą większość populacji miejskiej całego kraju. Czerwoni Khmerzy chcąc osiągnąć samowystarczalność gospodarczą, skupili się przede wszystkim na produkcji żywności. Niemal całe społeczeństwo zostało zmuszone do pracy przy uprawie ryżu, w warunkach, które z dzisiejszej perspektywy można określić jako niewolnicze ${ }^{5}$. Obywateli podzielono na dwie kategorie - „nowych ludzi”, czyli dotychczasowych mieszkańców miast i „starych ludzi”, przedstawicieli chłopstwa, którzy mieli stać się trzonem nowego bezklasowego społeczeństwa.

Demokratyczna Kampucza ${ }^{6}$ stała się państwem zamkniętym, bez możliwości zarówno wjazdu, jak i opuszczania kraju. Przestały funkcjonować szpitale i szkoły, zniesiono walutę, zburzono dziesiątki świątyń, a za udział w praktykach religijnych groziła kara śmierci. Szczególnym represjom, nierzadko torturom i egzekucjom, podlegała inteligencja i ludzie związani z poprzednimi reżimami, a także etniczni Wietnamczycy, Tajlandczycy i Chińczycy, których traktowano jako szpiegów ${ }^{7}$. Celowo rozbijano rodziny, nierzadko rozdzielano najbliższych już podczas ewakuacji z miast, nie pozwalano im mieszkać, bądź pracować w tym samym miejscu ${ }^{8}$. Odebrane rodzicom dzieci trafiały do osobnych obozów, gdzie były szczególnie indoktrynowane. Traktowano je jako „nieskażone przeszłością” i uczono je donosić na dorosłych, również członków swoich rodzin. Dzieci wykorzystywano także w działaniach zbrojnych, a spora część z nich bardzo szybko awansowała w szeregach Czerwonych Khmerów?

4 P. Short, Możecie być pewni, że umrzecie bezużytecznie, „Rzeczpospolita”, 11 III 2016, https://www. rp.pl/Plus-Minus/303119986-Mozecie-byc-pewni-ze-umrzecie-bezuzytecznie.html (5 V 2020).

5 O. Budrewicz, Cień potwora, „Wprost”, 4 II 2001, https://www.wprost.pl/tygodnik/9166/Cien-potwora.html (5 V 2020).

6 Dnia 5 I 1976 r. Czerwoni Khmerzy oficjalnie zmienili nazwę państwa - z Republika Khmerów na Demokratyczna Kampucza.

7 G. Wright, Unpunished Purge, „The Cambodia Daily”, 8 X 2016, https://english.cambodiadaily. com/features/unpunished-purge-118960/ (5 V 2020).

8 K. E. Mam, An Oral History of Family Life under the Khmer Rouge, „Yale Center for International and Area Studies. Genocide Studies Program” 1999, GS 10, https://www.files.ethz.ch/ isn/46615/GS10.pdf (5 V 2020).

9 Zob. Children in Cambodia under the Khmer Rouge, https://www.open.edu/openlearn/society-politics-law/children-and-violence-introductory-international-and-interdisciplinaryapproach/content-section-4.3.2 (5 V 2020). 
Niespełna cztery lata rządów Czerwonych Khmerów to również czas głodu. Destrukcja gospodarki i złe decyzje podejmowane w kontekście uprawy roli, doprowadziły do sytuacji, w której większości społeczeństwa brakowało pożywienia. Niedożywionych ludzi zmuszano do pracowania przez 18 godzin dziennie, siedem dni w tygodniu. Szacuje się jednak, że nawet połowa ofiar reżimu Czerwonych Khmerów zginęła w masowych egzekucjach ${ }^{10}$. Setki tysięcy ludzi zmarło z powodu braku leków, na choroby, które w normalnych warunkach byłyby wyleczalne ${ }^{11}$. W latach 1975-1979, w sposób nienaturalny, życie straciło około dwa miliony osób, prawie jedna czwarta mieszkańców Kambodży ${ }^{12}$.

Reżim Czerwonych Khmerów został obalony przez wojska wietnamskie i prowietnamski Zjednoczony Front Ocalenia Narodowego Kampuczy, skupiający khmerskich opozycjonistów. Konflikt między Wietnamem i Kampuczą przejawiał się głównie w potyczkach przygranicznych, a napięcie eskalowało przez cały okres rządów Pol Pota. Agresorem przeważnie była strona khmerska, mimo sporej dysproporcji w liczebności i zaopatrzeniu na korzyść wojsk wietnamskich. Doprowadziło to w ostateczności do inwazji wietnamskiej 25 XII 1978 r. i upadku Phnom Penh 7 I 1979 r. W kraju zainstalowano prowietnamski rząd, a dowództwo Czerwonych Khmerów schroniło się w Tajlandii i przystąpiło do wojny partyzanckiej z nowymi władzami. Konflikt między Wietnamem i Kambodżą trwał, podobnie jak wietnamska okupacja, kolejne 10 lat ${ }^{13}$.

Z pomocą ze strony Hanoi rozpoczął się żmudny proces odbudowy państwa, nie tylko w kontekście gospodarczym, lecz także społecznym. Już w 1979 r. podjęto pierwsze próby rozliczenia się z przeszłością dotyczącą wydarzeń, jakie rozegrały się za rządów Czerwonych Khmerów. Z inspiracji nowych władz utworzono Rewolucyjny Trybunał Ludowy, a ekspertami zostali prawnicy zarówno miejscowi, jak i zagraniczni. Organ ten miał orzec winę dwóch przywódców poprzedniego reżimu, Pol Pota i Ienga Sary’ego, choć pozostawali oni na wolności. W ciągu tygodnia trybunał wydał wyrok - kara śmierci (in absentia) dla obu oskarżonych. Choć co do funkcjonowania tego sądu, jego niezawisłości i wiarygodności zeznań świadków można mieć wiele wątpliwości, była to jedyna próba penalizacji

10 P. Heuveline, The Demographic Analysis of Mortality Crises: The Case of Cambodia, 19701979, [w:] Forced Migration \& Mortality, red. H. E. Reed, C. B. Keely, Waszyngton 2001.

11 A. Y. Guillou, Medicine in Cambodia during the Pol Pot Regime (1975-1979), Nowy Jork 2004, https://halshs.archives-ouvertes.fr/halshs-00327711/document (5 V 2020).

12 B. Kiernan, The Demography of Genocide in Southeast Asia: The Death Tolls in Cambodia, 1975-79, and East Timor, 1975-80, „Critical Asian Studies” 2003, vol. 35, s. 585-597.

13 Zakończenie konfliktu datuje się na 26 IX 1989 r., czyli dzień wycofania się ostatnich żołnierzy wietnamskich z terytorium Kambodży. P. Verieze, N. Vannarin, Remembering the Vietnamese, „The Cambodia Daily”, 2 IX 2009, https://english.cambodiadaily.com/stories-of-the-month/ remembering-the-vietnamese-330/ (5 V 2020). 
zbrodni popełnionych w czasach Demokratycznej Kampuczy, aż do czasu powołania Nadzwyczajnych Izb Sądów Kambodży w 2003 r. ${ }^{14}$.

Funkcjonowanie Rewolucyjnego Trybunału Ludowego było także pierwszym krokiem na drodze instytucjonalizacji procesu pojednania. W przypadku Kambodży do rekoncyliacji rozumianej jako „odbudowanie relacji”"15 wciąż nie doszło, choć od upadku rządów Czerwonych Khmerów minęło już ponad 40 lat. Aby zrozumieć uwarunkowania procesu pojednania w Kambodży trzeba przyjrzeć się przede wszystkim wydarzeniom, jakie miały miejsce w latach 1975-1979.

Ludobójstwo za rządów Demokratycznej Kampuczy miało charakter powszechny. Niemalże każdy obywatel Kambodży, niezależnie od pochodzenia, sytuacji finansowej, wyznania, płci, czy wieku, najczęściej w sposób bezpośredni stał się podmiotem terroru ze strony Czerwonych Khmerów lub był oprawcą ${ }^{16}$. Choć w latach 1975-1979 doszło do wielu zbrodni o podłożu etnicznym i religijnym, to jednak działania ugrupowania Pol Pota miały charakter uniwersalny i nawet „starzy ludzie”, którzy z założenia mieli być sojusznikami nowej władzy i stać się podłożem nowego społeczeństwa, również stawali się ofiarami reżimu. To różni przypadek Kambodży od większości ludobójstw, jakie miały miejsce w ostatnim półwieczu. Zazwyczaj takie zbrodnie popełniane są ze względów etnicznych, religijnych, bądź z powodu przynależności do określonej organizacji politycznej. W przypadku Kambodży ofiary i oprawcy często wywodzili się z tych samych miejscowości, a podział ze względu na wykształcenie czy sytuację materialną sprzed ludobójstwa nie rodził w ludziach poczucia odrębnej tożsamości. W Kambodży ludobójstwo nie stało się spoiwem, punktem zbiorowej identyfikacji, czynnikiem budującym tożsamość, jak często ma to miejsce w przypadku mniejszości, które spotkały podobne tragiczne wydarzenia.

Brak wyraźnego podziału między ofiarami i oprawcami jest spowodowany sposobem w jaki Czerwoni Khmerzy rekrutowali nowych członków po dojściu do władzy. W momencie zdobywania Phnom Penh w szeregach ugrupowania Pol Pota było od 50 do 80 tys. członków ${ }^{17}$. Rozbudowany aparat terroru i systemu obozów pracy potrzebował jednak dużo większego personelu. Wielu oprawców z czasów Demokratycznej Kampuczy twierdziło, że byli przymuszeni do wyko-

14 P. Milik, Proces Pol Pota i Ieng Sary przed Rewolucyjnym Trybunałem Ludowym, 2 IX 2011, http://www.psz.pl/117-polityka/proces-pol-pota-i-ieng-sary-przed-rewolucyjnym-trybunalem-ludowym (5 V 2020).

15 J. Kulska, Rola pojednania w relacyjnym podejściu do rozwiązywania konfliktów, „Wschodnioznawstwo" 2016, s. 11-26.

16 Niejednokrotnie ofiary stawały się z biegiem czasu oprawcami i w wielu przypadkach niemożliwym jest oddzielenie jednych od drugich.

17 Przesłuchania przed Komisją ds. Spraw Międzynarodowych Izby Reprezentantów USA, The Vietnam-Cambodia Emergency, 1975. Part 1 - Vietnam Evacuation and Humanitarian Asssistance, Waszyngton 1976, s. 305 
nywania rozkazów, w tym mordowania ludzi, gdyż w innym wypadku sami zostaliby straceni. Należy również pamiętać o specjalnej roli dzieci w ludobójstwie. Indoktrynowano je, uczono szpiegować i denuncjować dorosłych, również ze swoich rodzin, a także przymusowo wcielano je w szeregi Czerwonych Khmerów i sił zbrojnych Kampuczy. Nierzadko dzieci w wieku lat 12 obejmowały stanowiska kierownicze i dowodziły obozami pracy, wykazując się przy tym szczególnym okrucieństwem. Po upadku reżimu pozostał w społeczeństwie Kambodży „szczątkowy strach przed dziećmi”" ${ }^{18}$. Jest to kolejny czynnik utrudniający proces pojednania. Dziesiątki tysięcy dzieci, pozbawionych rodziców, zmanipulowanych i przekonanych o słuszności ideologii wpojonej im przez nową władzę, było oprawcami, nie rozumiejąc tak naprawdę swoich czynów.

Separacja rodzin, żon od mężów i dzieci od rodziców, która w zamyśle Czerwonych Khmerów miała osłabiać dotychczasowe więzy, przeszkadzające w budowie nowego społeczeństwa, również ma negatywny wpływ na proces pojednania. Po pierwsze, spora część ludzi nie wie co się stało z członkami ich rodzin, a brak dokumentacji z czasów Demokratycznej Kampuczy uniemożliwia odnalezienie jakichkolwiek informacji o ich losie. Skala ludobójstwa uniemożliwia także identyfikację szczątków. Po drugie, ugrupowanie Pol Pota prowadziło masową relokację ludności. Niejednokrotnie członkowie rodzin trafiali do obozów oddalonych o setki kilometrów od ich miejsca zamieszkania i miejsc, do których skierowano ich małżonków, czy dzieci. Po upadku reżimu Czerwonych Khmerów spora część osób nie była w stanie wrócić do miejsc, które zamieszkiwała przed 1975 r., z powodów zdrowotnych, czy finansowych. Wiele osób straciło wszystkich członków swoich rodzin. Osierocone lub oddzielone od rodziców dzieci, zdezorientowane całą sytuacją, często nie pamiętały, bądź nie wiedziały skąd pochodzą i w jaki sposób mogą odnaleźć żyjących krewnych. Ponad milion Kambodżan, uciekając przed głodem i wojną, szukało schronienia poza granicami kraju, przede wszystkim w sąsiedniej Tajlandii ${ }^{19}$. Zmiana miejsca zamieszkania była też często formą zerwania z okrutną przeszłością.

Po upadku Demokratycznej Kampuczy tysiące osób, szczególnie byli członkowie ugrupowania Pol Pota, ukrywało swoją tożsamość, aby nie spotkać się z ostracyzmem ze strony reszty społeczeństwa. Ludzie ci zdawali sobie sprawę z okrucieństw, jakie dokonali, a także jaką rolę pełnili za rządów Czerwonych Khmerów. Wielu z nich działało wbrew własnej woli, ze strachu o życie swoje lub bliskich. Większość rekrutów była bardzo młoda i słabo wykształcona. Wielu khmerskich chłopów przyłączało się do rewolucjonistów lub sympatyzowało

Children in Cambodia...

19 P. Rungswasdisab, Thailand's Response to the Cambodian Genocide, „Yale Center for International and Area Studies. Genocide Studies Program” 1999, GS 21, https://www.files.ethz.ch/ isn/46648/GS21.pdf (5 V 2020). 
z nimi, gdyż dotychczasowi rządzący bardzo rzadko reprezentowali ich interesy. Co więcej, przed 17 IV 1975 r. Czerwoni Khmerzy mieli poparcie społeczne nawet wśród mieszkańców miast. W wielu relacjach opisujących upadek Phnom Penh znajdziemy wzmianki o tym, jak mieszkańcy radośnie witali wchodzących do miasta komunistów, ciesząc się z końca wojny i upadku reżimu Lon Nola ${ }^{20}$. Niegdysiejsza akceptacja dla działań ugrupowania Pol Pota i identyfikowanie się z głoszoną przez nich ideologią często jest powodem wstydu wśród Kambodżan, co dodatkowo potęguje zamknięcie na niezbędny w procesie pojednania dialog.

Sytuacja polityczna, jaka nastąpiła w Kambodży po upadku Demokratycznej Kampuczy, zaszkodziła rekoncyliacji. Resztki sił Czerwonych Khmerów schroniły się na pograniczu tajlandzko-kambodżańskim, a wojska wietnamskie pozostały w kraju, okupując go. Doprowadziło to do konfliktu, który trwał całą następną dekadę. W 1982 r. powstał Koalicyjny Rząd Demokratycznej Kampuczy, w skład którego wchodzili prawicowi antykomuniści, monarchiści pod przywództwem obalonego króla Sihanouka, a także Czerwoni Khmerzy, którzy stanowili w tymże ugrupowaniu większość. Ta opozycyjna względem prowietnamskich władz organizacja pełniła rolę rządu na uchodźctwie i funkcjonowała jako reprezentacja Kambodży w ONZ aż do 1993 r. Co zaskakujące, było to możliwe tylko dzięki poparciu Stanów Zjednoczonych i większości państw zachodnich, które mimo pełnej świadomości o zbrodniczej przeszłości ugrupowania Pol Pota postanowiły poprzeć ich roszczenia ${ }^{21}$. Ta dość osobliwa sytuacja, w której komunistyczni zbrodniarze jednoczą siły z monarchistami i republikanami, a na dodatek mają poparcie ze strony państw Zachodu, utrudniała interpretację wydarzeń z czasów Demokratycznej Kampuczy.

Podobny dysonans wywoływała proweniencja członków Kampuczańskiego Zjednoczonego Frontu Narodowego Ocalenia, którzy stanęli na czele Ludowej Republiki Kampuczy. Większość nowego kierownictwa stanowili byli Czerwoni Khmerzy, którzy zostali odsunięci od władzy podczas wewnątrzpartyjnych czystek. Zbiegli do pobliskiego Wietnamu, gdzie się przegrupowali, zorganizowali i wraz z wietnamskim wojskiem obalili swoich niedawnych przełożonych. Szczególnie ważne dla najnowszej historii Kambodży są trzy nazwiska. Po pierwsze Heng Samrin, sekretarz generalny Kambodżańskiej Partii Ludowej w latach

20 Wielu mieszkańców Phnom Penh zwraca uwagę na powszechną radość, jaka miała zagościć na ulicach stolicy 17 IV 1975 r. Zob. Wspomnienia świadków zebrane przez Documentation Center of Cambodia, http://factsanddetails.com/southeast-asia/Cambodia/sub5_2b/entry-2851.html\#chapter-13 (5 V 2020).

21 Był to wynik zimnowojennej rozgrywki. Wsparcie dla Koalicyjnego Rządu Demokratycznej Kampuczy traktowano na Zachodzie jako ograniczanie wpływów radzieckich, gdyż Socjalistyczna Republika Wietnamu i Ludowa Republika Kampuczy były sojusznikami ZSRR. Czerwoni Khmerzy odcinali się od Związku Radzieckiego, widząc swojego najważniejszego sojusznika w Chińskiej Republice Ludowej. 
1981-1991 i de facto przywódca państwa w latach 1979-1992, który w czasach Demokratycznej Kampuczy był komisarzem politycznym i dowódcą dywizji ${ }^{22}$. Po drugie Chea Sim, przywódca Kambodżańskiej Partii Ludowej w latach 19912015 i wieloletni przewodniczący Zgromadzenia Narodowego, a także Senatu Kambodży, który będąc członkiem Czerwonych Khmerów pełnił funkcję sekretarza komitetu partii w jednej ze stref ${ }^{23}$. Wreszcie Hun Sen, aktualny premier Kambodży, pełniący urząd od przeszło 35 lat ${ }^{24}$, od 2015 r. także przewodniczący Kambodżańskiej Partii Ludowej. W szeregi Czerwonych Khmerów wstąpił jako 18-latek, w 1970 r., gdzie w imponujący sposób wspinał się po ścieżce kariery. W momencie ucieczki z kraju był zastępcą dowódcy pułku i dowodził przeszło dwoma tysiącami żołnierzy ${ }^{25}$. Co do każdego z nich istnieją przypuszczenia dotyczące aktywnego udziału w ludobójstwie. Samrin jest najwyższym rangą żyjącym dowódcą, który brał udział w ewakuacji Phnom Penh, a wraz z Simem uczestniczyli w konferencji, która odbyła się $20 \mathrm{~V} 1975$ r. ${ }^{26}$. To właśnie na tym spotkaniu oficjalnie rozpoczęto wdrażanie polityki, której efektem była śmierć milionów Kambodżan ${ }^{27}$.

Konsekwencje tej sytuacji są widoczne po dziś dzień. Wydaje się, że jest to zasadniczy powód braku woli władz Kambodży, aby penalizować oprawców niższej rangi. Po pierwsze, wielu polityków i osób skupionych wokół Kambodżańskiej Partii Ludowej, na czele z premierem, mogłoby być postawionych w stan oskarżenia. Po drugie, tysiące Kambodżan w pewnym momencie swojego życia identyfikowało się i niejednokrotnie wstępowało do ruchu Czerwonych Khmerów, często brało udział w ludobójstwie, lecz nie pozostało wiernym Pol Potowi i po upadku Demokratycznej Kampuczy odżegnywało się od głoszonych przez niego idei. Władze Ludowej Republiki Kampuczy nie widziały potrzeby postawienia tych osób przed wymiarem sprawiedliwości, gdyż wielu z rządzących przeszło identyczną drogę. Natomiast ci, którzy pozostali, nadal bronili postulatów z lat

22 J. C. Liow, Dictionary of the Modern Politics of Southeast Asia, Londyn 2014, s. 121.

23 Ibidem, s. 178.

24 W latach 1993-1997 urząd premiera w Kambodży był kolegialny. Hun Sen pełnił to stanowisko wraz z Norodomem Ranariddhem. Zob. M. Jońca, Hun Sen rządzi Kambodża już od 35 lat, 20 II 2020, http://pulsazji.pl/2020/02/20/hun-sen-rzadzi-kambodza-juz-od-35-lat/ (6 V 2020).

25 B. Adams, 30 Years of Hun Sen. Violence, Repression, and Corruption in Cambodia, 12 I 2015, https://www.hrw.org/report/2015/01/12/30-years-hun-sen/violence-repression-and-corruption-cambodia\#e00b6b (6 V 2020).

26 B. Kiernan, Genocide and Resistance in Southeast Asia: Documentation, Denial, and Justice in Cambodia and East Timor, Londyn 2008, s. 71-77.

27 Od 1984 r. 20 V jest obchodzony w Kambodży jako Narodowy Dzień Pamięci (Nienawiści). Zob. Cambodian Day of Hate Marks Pol Pot's Victims, „The New York Times”, 21 V 1984, https://www.nytimes.com/1984/05/21/world/around-the-world-cambodian-day-of-hatemarks-pol-pot-s-victims.html (6 V 2020). 
1975-1979 i prowadzili wojnę partyzancką przeciwko nowym władzom, również musieli zweryfikować swoje podejście. W 1981 r. Czerwoni Khmerzy oficjalnie odrzucili komunizm na rzecz bardziej nacjonalistycznej polityki ${ }^{28}$, co pozwoliło im zbliżyć się do prawicowej części opozycji.

Odcinanie się od traumatycznych wydarzeń z czasów Demokratycznej Kampuczy, ukrywanie swoich tożsamości, dylematy moralne, które potęgował brak stabilności politycznej, a także fakt, że członków rządu i opozycji oskarżano o bycie oprawcami, doprowadziły do sytuacji, w której proces pojednania w czasach Ludowej Republiki Kampuczy został zahamowany. Trwający wciąż konflikt zbrojny, jak i problemy wewnętrzne związane z biedą i potrzebą odbudowy gospodarki, wydawały się dużo ważniejsze, niż działania na rzecz rekoncyliacji. Kwestia odpowiedzialności za popełnione przez Czerwonych Khmerów zbrodnie powróciła na przełomie lat 80. i 90., kiedy to doszło do zbliżenia premiera Hun Sena z opozycją i zakończenia wojny wietnamsko-kambodżańskiej. Ostatecznie konflikt został zażegnany na konferencji pokojowej, która miała miejsce w Paryżu w 1991 r. Reprezentanci Czerwonych Khmerów również brali w niej udział, co wymusiło na zgromadzonych unikania kwestii odpowiedzialności za zbrodnie popełnione w czasach Demokratycznej Kampuczy ${ }^{29}$. Jednakże oficjalny powrót do kraju decydentów z lat 1975-1979 wywołał w społeczeństwie skrajne emocje. Gdy Khieu Samphan przyleciał do Kambodży 27 XI 1991 r., aby wziąć udział w kampanii wyborczej, w Phnom Penh wybuchły zamieszki, a rozwścieczony tłum zaatakował posiadłość, w której przebywał. Samphan, przewodniczący Rady Państwa w czasach Demokratycznej Kampuczy, został dotkliwie pobity i wraz $\mathrm{z}$ resztą delegacji zdecydował się opuścić kraj ${ }^{30}$.

Ta sytuacja unaoczniła Czerwonym Khmerom, że ich uczestnictwo w życiu politycznym w Kambodży jest niemożliwe, szczególnie w kształcie, który został określony podczas konferencji paryskiej. Odmówili więc rozbrojenia swoich oddziałów, zbojkotowali demokratyczne wybory i rozpoczęli wojnę partyzancką z nowymi władzami i siłami ONZ, które stacjonowały wtedy w Kambodży. Pozbawieni sojuszników i zewnętrznego wsparcia nie mieli szans na obalenie rządu, aczkolwiek kontrolowali kilka prowincji przy granicy z Tajlandią. Jednakże w latach 90. doszło do wielu rozłamów w szeregach Czerwonych Khmerów, co znacznie osłabiło ich pozycję. Ieng Sary, członek Komitetu Centralnego, minister

28 K. Rowley, Second Life, Second Death: The Khmer Rouge After 1978, „Yale Center for International and Area Studies. Genocide Studies Program” 2006, GS24, https://www.files.ethz.ch/ isn/46657/GS24.pdf (6 V 2020).

29 C. Atkins, Cambodian's Peace: Genocide, Justice and Silence, „The Washington Post”, 26 I 1992, https://www.washingtonpost.com/archive/opinions/1992/01/26/cambodias-peace-genocidejustice-and-silence/1bdf2edc-238b-4d82-bd7b-b801766c4455/ (6 V 2020).

30 Khmer Rouge Chief Flees Cambodia After Beating, „Los Angeles Times”, 28 XI 1991, https:// www.latimes.com/archives/la-xpm-1991-11-28-mn-154-story.html (6 V 2020). 
spraw zagranicznych i wicepremier w czasach Demokratycznej Kampuczy, oddał się w 1996 r. w ręce rządu. W zamian za to udzielono mu aktu łaski, anulując karę śmierci zasądzoną w 1979 r. i zwolniono z odpowiedzialności karnej. Dwa lata wcześniej ogłoszono również amnestię dla członków organizacji politycznej i sił zbrojnych Demokratycznej Kampuczy, którym pozwolono na powrót do kraju i zagwarantowano, że nie będą pociągnięci do odpowiedzialności za swoje czyny. Amnestia nie dotyczyła jednak przywódców ruchu ${ }^{31}$.

To doskonale pokazuje jaka atmosfera panowała w Kambodży w latach 90. ubiegłego wieku. Walkę zbrojną próbowano przekształcić w rywalizację polityczną, zgodnie z zasadami demokracji. Masowe dezercje i przechodzenie na stronę rządową byłych przywódców Czerwonych Khmerów doprowadziły do czystek wewnątrz organizacji ${ }^{32}$. Sam Pol Pot został odsunięty od władzy i aresztowany przez towarzyszy. Ugrupowanie zostało ostatecznie rozbite na przełomie 1998 i 1999 r. Większość byłych Czerwonych Khmerów pozostało w prowincji Pailin, ostatnim bastionie ruchu ${ }^{33}$. Po niemalże trzydziestu latach walk w Kambodży zapanował tak ważny dla procesu pojednania pokój.

Jeszcze w 1997 r. obaj premierzy Kambodży wystosowali list do Sekretarza Generalnego ONZ z prośbą o utworzenie międzynarodowego trybunału, który miałby zająć się sprawą zbrodni popełnionych w czasach Demokratycznej Kampuczy. Jednakże ostateczny kształt takiej instytucji określono dopiero w 2003 r., po sześciu latach negocjacji między Phnom Penh a organami ONZ. Faktyczne funkcjonowanie Nadzwyczajnych Izb Sądów Kambodży rozpoczęło się po kolejnych czterech latach, kiedy rozpoczęto postępowania wobec pierwszych oskarżonych ${ }^{34}$. Do końca 2019 r. przed wymiarem sprawiedliwości postawiono jedynie 5 osób, z czego dwie zmarły zanim usłyszały wyrok ${ }^{35}$. Procesy innych przywódców Czerwonych Khmerów są niepewne i nie postawiono ich jeszcze w stan oskarżenia ${ }^{36}$.

31 K. Holy, Prawo międzynarodowe publiczne wobec amnestii, Warszawa 2015, s. 105-106.

32 D. Ashley, Between war and peace: Cambodia 1991-1998, „Accord”, listopad 1998, https:// www.c-r.org/accord/cambodia/between-war-and-peace-cambodia-1991-1998 (6 V 2020).

33 D. Eimer, Khmer Rouge killers live in contented retirement as Cambodia struggles with the legacy of Pol Pot, „The Telegraph”, 21 VII 2013, https://www.telegraph.co.uk/news/worldnews/ asia/cambodia/10192536/Khmer-Rouge-killers-live-in-contented-retirement-as-Cambodiastruggles-with-the-legacy-of-Pol-Pot.html (6 V 2020).

34 P. Grzebyk, Kambodżańska droga do sprawiedliwości, [w:] Azja Wschodnia i Azja Południowa w stosunkach międzynarodowych. Bezpieczeństwo - Gospodarka - Cywilizacja, red. J. Nakonieczna, J. Zajączkowski, Warszawa 2011, s. 201-222.

35 Kang Kek Iew, Khieu Samphan i Nuon Chea (zmarł w 2019 r.) skazani zostali na dożywotnie pozbawienie wolności. Ieng Sary i Ieng Thirith zmarli zanim usłyszeli wyrok. Ta Mok, przetrzymywany w areszcie od 1999 r., zmarł w 2006 r., zanim rozpoczęto procesy.

36 L. Hunt, Cambodia and the Khmer Rouge: Between Justice and Memory, 30 VII 2019, https:// thediplomat.com/2019/07/cambodia-and-the-khmer-rouge-between-justice-and-memory/ (7 V 2020). 
Nadzwyczajne Izby są krytykowane za swoją nieefektywność i upolitycznienie ${ }^{37}$. Prośby wysyłane do polityków skupionych wokół aktualnego premiera o stawienie się przed Izbami w charakterze świadka były wielokrotnie odrzucane ${ }^{38}$. Wątpliwości dotyczące organizacji całej instytucji, ograniczenie zainteresowania jedynie do czołowych działaczy Czerwonych Khmerów, czy długość trwania procesów spowodowały, iż organ ten jest negatywnie odbierany zarówno przez zagranicznych obserwatorów, jak i społeczeństwo Kambodży. Niesatysfakcjonujące próby penalizacji odpowiedzialnych za zbrodnie popełnione w latach 1975-1979 negatywnie wpływają na przebieg procesu pojednania w Kambodży.

Historyczne, polityczne i społeczne uwarunkowania rekoncyliacji należy jednak uzupełnić o czynnik kulturowy, najtrudniejszy do uchwycenia. Sfera ta, nierzadko istotniejsza od pozostałych, stała się największą przeszkodą w procesie pojednania w Kambodży. Wyparcie i ogólna niechęć do dzielenia się wspomnieniami dotyczącymi czasów Demokratycznej Kampuczy, to efekt strachu, wstydu i traumy. Przez lata temat ludobójstwa nie pojawiał się w mediach, a do 2009 r. pomijano go nawet w podręcznikach szkolnych ${ }^{39}$. Milczenie zaczęto przełamywać dopiero po prawie 30 latach od upadku reżimu Czerwonych Khmerów. Dziesięciolecia milczenia, w których ofiary starały się pomijać temat okrucieństw jakie wydarzyły się w latach 1975-1979, doprowadziły do sytuacji, w której trauma przeszła na kolejne pokolenia. Setki tysięcy ludzi dotkniętych zespołem stresu pourazowego, lub innymi zaburzeniami psychicznymi powstałymi na skutek wcześniejszych przeżyć, nie było w stanie znaleźć pomocy i było izolowane. Przemoc, również domowa, dysfunkcyjne rodziny, społeczeństwo, w którym brakuje jakiegokolwiek zaufania do drugiej osoby, stały się prawdziwym obliczem Kambodży ${ }^{40}$. To wszystko potęgowane przez biedę i niestabilność polityczną doprowadziło do sytuacji, w której po dziś dzień brakuje warunków do zaistnienia pojednania.

Od upadku rządów Czerwonych Khmerów wyrosły dwa pokolenia Kambodżan, a spora część świadków wydarzeń z lat 1975-1979 zmarła, bądź znajduje się

37 C. Campbell, Cambodia's Khmer Rouge Trials Are a Shocking Failure, „Time”, 13 II 2014, https://time.com/6997/cambodias-khmer-rouge-trials-are-a-shocking-failure/ (7 V 2020).

38 G. Wright, Heng Samrin's Absence Leaves Holes at Tribunal, „The Cambodia Daily”, 23 VIII 2016, https://english.cambodiadaily.com/editors-choice/heng-samrins-absence-leaves-holestribunal-117023/ (7 V 2020).

39 K. Dy, Challenges of Teaching Genocide in Cambodian Secondary Schools, „Policy and Practice: Pedagogy about the Holocaust and Genocide Papers" 2013, http://ticambodia.org/library/wpcontent/files_mf/1436954165ChallengesofteachingGenocideinCambodiainsecondaryschool. $\operatorname{pdf}(7 \mathrm{~V} 2020)$.

40 Syndrom „złamanej odwagi”, który jest kulturowym odbiciem traumy, opisuje w wywiadzie Wojciech Tochman, autor nagradzanego reportażu o Kambodży. Zob. T. Zimmerman, Wojciech Tochman: za uśmiechami Khmerów kryje się złamana odwaga, 8 III 2019, https:// wiadomosci.onet.pl/tylko-w-onecie/wojciech-tochman-za-usmiechami-khmerow-kryje-siezlamana-odwaga/s5ch3ty (7 V 2020). 
na skraju życia ${ }^{41}$. Mimo działań na rzecz pojednania, jakie miały miejsce głównie w aktualnym stuleciu, nie można powiedzieć o zakończeniu tego procesu. Należy zadać pytanie - czy po ponad czterdziestu latach od ludobójstwa, po których nastąpił okres milczenia i wyparcia, jest jeszcze możliwe osiągnięcie pojednania? Relacje międzyludzkie nigdy nie wróciły do stanu równowagi, również wśród pokoleń, które urodziły się już po 1979 r. Tylko chęć dotarcia do „prawdy” o Demokratycznej Kampuczy, cierpieniu ofiar, motywacji oprawców, roli, jaką w ludobójstwie odegrali oni sami, bądź ich przodkowie, może zbliżyć Kambodżan do pojednania. Choć minęły już cztery dekady od obalenia ugrupowania Pol Pota, to społeczeństwo nadal nie wydaje się być gotowe na takie działania. Symbolem zawiłej sytuacji politycznej, braku zaangażowania i trudności, jakie stoją na przeszkodzie rekoncyliacji powinien być fakt, że krajem nieprzerwanie od 35 lat rządzi Hun Sen, były Czerwony Khmer.

\section{Abstract \\ Radosław Zarzecki \\ Determinants of Reconciliation in Cambodia}

Forty years after Cambodian genocide the reconciliation is still in early stage. Despite such long time there was almost nothing done, especially in $20^{\text {th }}$ century, to make that process happened. The article discusses the determinants, reasons and factors that had impact on reconciliation. Determinants can be divided into different categories. First of all the socio-historical background. Circumstances in which Khmer Rouge come to power, their revolutionary approach to economy, implemented reforms, use of children, displacements of people and categorization of citizens had great impact on post-1979 Cambodia. Another determinant is a political one. Policy of post-Khmer Rouge Cambodia rulers stunted the reconciliation. There reason of such actions are multidimensional but the most important one is provenance of People's Republic of Kampuchea leaders. The most important figures in Cambodia politics are ex-Khmer Rouge soldiers, accused by some of taking a part in genocide. What's even more confusing, the most powerful opposition party in 1980s were perpetrators themselves and their allies. Even after signing Paris Peace Accords in 1991 until early 2000s there was no will to punish Khmer Rouge officials responsible for genocide. The Cambodian culture

${ }^{41}$ Średnia długość życia w Kambodży wynosi niespełna 70 lat. Zob. Dane Banku Światowego dotyczące średniej długości życia w Kambodży (stan na 2019 r.), https://data.worldbank.org/ indicator/SP.DYN.LE00.IN?locations=KH (7 V 2020). 
of silence, the third determinant, only exacerbates a difficult situation. Cambodians rarely speak about atrocities and harsh past because of fear, shame or trauma. Even in school textbooks until 2009 there was almost nothing said about tragic events which happened between 1975 and 1979. History of Democratic Kampuchea still affects the Cambodian society. Despite sentencing few Khmer Rouge officials in 2010s, there's still lot to be done also on state-level. Reconciliation and coming back to the state of balance is the main challenge for Cambodia in the nearest future, crucially important to social and political life of this nation.

Keywords: Cambodia, Cambodian genocide, Democratic Kampuchea, Khmer Rouge, reconciliation

\section{References}

Adams, B., 30 Years of Hun Sen. Violence, Repression, and Corruption in Cambodia, „Human Rights Watch”, 12 I 2015.

Ashley, D., Between war and peace: Cambodia 1991-1998, „Accord”, XI 1998.

Atkins, C., Cambodian's Peace: Genocide, Justice and Silence, „The Washington Post", 26 I 1992.

Budrewicz, O., Cień potwora, „Wprost”, 4 II 2001.

Cambodian Day of Hate Marks Pol Pot's Victims, „The New York Times”, 21 V 1984.

Campbell, C., Cambodia's Khmer Rouge Trials Are a Shocking Failure, „Time”, 13 II 2014.

Children in Cambodia under the Khmer Rouge, https://www.open.edu/openlearn/ society-politics-law/children-and-violence-introductory-international-andinterdisciplinary-approach/content-section-4.3.2.

Dy, K., Challenges of Teaching Genocide in Cambodian Secondary Schools, „Policy and Practice: Pedagogy about the Holocaust and Genocide Papers" 2013.

Eimer, D., Khmer Rouge killers live in contented retirement as Cambodia struggles with the legacy of Pol Pot, „The Telegraph”, 21 VII 2013.

Grzebyk, P., Kambodżańska droga do sprawiedliwości, [in:] Azja Wschodnia i Azja Południowa w stosunkach międzynarodowych. Bezpieczeństwo - Gospodarka Cywilizacja, eds. J. Nakonieczna, J. Zajączkowski, Warszawa 2011.

Guillou, A. Y., Medicine in Cambodia during the Pol Pot Regime (1975-1979), New York 2004.

Heuveline, P., The Demographic Analysis of Mortality Crises: The Case of Cambodia, 1970-1979, [in:] Forced Migration \& Mortality, eds. H. E. Reed, B. C. Keely, Washington 2001. 
Holy, K., Prawo międzynarodowe publiczne wobec amnestii, Warszawa 2015.

Hunt, L., Cambodia and the Khmer Rouge: Between Justice and Memory, 30 VII 2019, https://thediplomat.com/2019/07/cambodia-and-the-khmer-rouge-between-justice-and-memory/.

Jońca, M., Hun Sen rządzi Kambodża już od 35 lat, „Puls Azji”, 20 II 2020.

Khmer Rouge Chief Flees Cambodia After Beating, „Los Angeles Times”, 28 XI 1991. Kiernan, B., Genocide and Resistance in Southeast Asia: Documentation, Denial, and Justice in Cambodia and East Timor, London 2008.

Kiernan, B., The Demography of Genocide in Southeast Asia: The Death Tolls in Cambodia, 1975-79, and East Timor, 1975-80, „Critical Asian Studies” 2003, vol. 35 .

Kulska, J., Rola pojednania w relacyjnym podejściu do rozwiązywania konfliktów, „Wschodnioznawstwo” 2016.

Lamothe, D., Vietnam remembered: The fall of Saigon in photos, 40 years later, „The New York Times”, 30 IV 2015.

Liow, J. C., Dictionary of the Modern Politics of Southeast Asia, London 2014.

Mam, K. E., An Oral History of Family Life under the Khmer Rouge, „Yale Center for International and Area Studies. Genocide Studies Program” 1999, GS 10.

Milik, P., Proces Pol Pota i Ieng Sary przed Rewolucyjnym Trybunałem Ludowym, 2 IX 2011, http://www.psz.pl/117-polityka/proces-pol-pota-i-ieng-saryprzed-rewolucyjnym-trybunalem-ludowym.

Owen, T., Kiernan, B., Bombs over Cambodia, „The Asia-Pacific Journal”, 12 V 2007. Rowley, K., Second Life, Second Death: The Khmer Rouge After 1978, „Yale Center for International and Area Studies. Genocide Studies Program” 2006, GS 24.

Rungswasdisab, P., Thailand's Response to the Cambodian Genocide, „Yale Center for International and Area Studies. Genocide Studies Program” 1999, GS 21.

Short, P., Możecie być pewni, że umrzecie bezużytecznie, „Rzeczpospolita”, 11 III 2016.

The Vietnam-Cambodia Emergency, 1975. Part 1 - Vietnam Evacuation and Humanitarian Asssistance, Washington 1976.

Verieze, P., Vannarin, N., Remembering the Vietnamese, „The Cambodia Daily”, 2 IX 2009.

Wang, C., The Chinese Communist Party's Relationship with the Khmer Rouge in the 1970s: An Ideological Victory and a Strategic Failure, „CWIHP Working Paper 88", XII 2018.

Wright, G., Heng Samrin's Absence Leaves Holes at Tribunal, „The Cambodia Daily, 23 VIII 2016.

Wright, G., Unpunished Purge, „The Cambodia Daily”, 8 X 2016.

Zimmerman, T., Wojciech Tochman: za uśmiechami Khmerów kryje się złamana odwaga, 8 III 2019, https://wiadomosci.onet.pl/tylko-w-onecie/wojciechtochman-za-usmiechami-khmerow-kryje-sie-zlamana-odwaga/s5ch3ty. 
Radosław Zarzecki - mgr stosunków międzynarodowych, doktorant w Zakładzie Badań Wschodnich w Instytucie Studiów Międzynarodowych Uniwersytetu Wrocławskiego w ramach Kolegium Doktorskiego Nauk o Bezpieczeństwie.

ORCID: 0000-0001-9033-9857 